University of Nebraska - Lincoln

DigitalCommons@University of Nebraska - Lincoln

$12-2015$

\title{
Background differences in baseline and stimulated MMP levels influence abdominal aortic aneurysm susceptibility
}

\author{
Matthew A. Dale \\ University of Nebraska Medical Center \\ Melissa K. Suh \\ University of Nebraska Medical Center \\ Shijia Zhao \\ University of Nebraska-Lincoln \\ Trevor Meisinger \\ University of Nebraska Medical Center, tmeisinger@unmc.edu \\ Linxia Gu \\ University of Nebraska-Lincoln, gul@fit.edu \\ Follow this and additional works at: https://digitalcommons.unl.edu/mechengfacpub

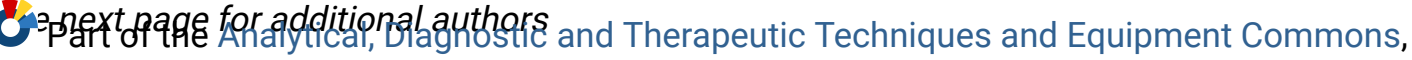 \\ Biochemistry, Biophysics, and Structural Biology Commons, Biomedical Engineering and Bioengineering \\ Commons, Biotechnology Commons, Cardiology Commons, Cardiovascular System Commons, Other \\ Engineering Commons, and the Surgery Commons
}

Dale, Matthew A.; Suh, Melissa K.; Zhao, Shijia; Meisinger, Trevor; Gu, Linxia; Swier, Vicki J.; Agrawal, Devendra K.; Greiner, Timothy; Carson, Jeffrey S.; Baxter, B. Timothy; and Xiong, Wanfen, "Background differences in baseline and stimulated MMP levels influence abdominal aortic aneurysm susceptibility" (2015). Mechanical \& Materials Engineering Faculty Publications. 124.

https://digitalcommons.unl.edu/mechengfacpub/124

This Article is brought to you for free and open access by the Mechanical \& Materials Engineering, Department of at DigitalCommons@University of Nebraska - Lincoln. It has been accepted for inclusion in Mechanical \& Materials Engineering Faculty Publications by an authorized administrator of DigitalCommons@University of Nebraska Lincoln. 


\section{Authors}

Matthew A. Dale, Melissa K. Suh, Shijia Zhao, Trevor Meisinger, Linxia Gu, Vicki J. Swier, Devendra K. Agrawal, Timothy Greiner, Jeffrey S. Carson, B. Timothy Baxter, and Wanfen Xiong 


\title{
Background differences in baseline and stimulated MMP levels influence abdominal aortic aneurysm susceptibility
}

\author{
Matthew A. Dale, ${ }^{1,4}$ Melissa K. Suh, ${ }^{1}$ Shijia Zhao, ${ }^{2}$ Trevor Meisinger, ${ }^{1}$ Linxia Gu, ${ }^{2}$ \\ Vicki J. Swier, ${ }^{3}$ Devendra K. Agrawal, ${ }^{3}$ Timothy C. Greiner, ${ }^{4}$ Jeffrey S. Carson, ${ }^{1}$ \\ B. Timothy Baxter, ${ }^{1,4}$ and Wanfen Xiong ${ }^{1}$ \\ 1 Department of Surgery, University of Nebraska Medical Center, Omaha, NE \\ 2 Department of Mechanical \& Materials Engineering, University of Nebraska-Lincoln, Lincoln, NE \\ 3 Department of Biomedical Sciences, Creighton University School of Medicine, Omaha, NE \\ 4 Department of Pathology and Microbiology, University of Nebraska Medical Center, Omaha, NE
}

Corresponding author - W. Xiong, University of Nebraska Medical Center, 987690 Nebraska Medical Center, Omaha, NE 68198-7690, USA; tel 402 559-7193; fax 402 559-6732; email wxiong@unmc.edu

\begin{abstract}
Objective: Evidence has demonstrated profound influence of genetic background on cardiovascular phenotypes. Murine models in Marfan syndrome (MFS) have shown that genetic background-related variations affect thoracic aortic aneurysm formation, rupture, and lifespan of mice. MFS mice with $\mathrm{C} 57 \mathrm{Bl} / 6$ genetic background are less susceptible to aneurysm formation compared to the $129 / \mathrm{SvEv}$ genetic background. In this study, we hypothesize that susceptibility to abdominal aortic aneurysm (AAA) will be increased in 129/SvEv mice versus C57Bl/6 mice. We tested this hypothesis by assessing differences in aneurysm size, tissue properties, immune response, and MMP expression.

Methods: Mice of C57Bl/6 or 129/SvEv background underwent AAA induction by periaortic application of CaCl2. Baseline aortic diameters, tissue properties and MMP levels were measured. After aneurysm induction, diameters, MMP expression, and immune response (macrophage infiltration and bone marrow transplantation) were measured.

Results: Aneurysms were larger in $129 / \mathrm{SvEv}$ mice than $\mathrm{C} 57 \mathrm{Bl} / 6$ mice $(83.0 \% \pm 13.6$ increase compared to $57.8 \% \pm 6.4)$. The aorta was stiffer in the $129 / \mathrm{SvEv}$ mice compared to $\mathrm{C} 57 \mathrm{Bl} / 6$ mice $(952.5 \mathrm{kPa} \pm 93.6$ versus $621.4 \mathrm{kPa} \pm 84.2)$. Baseline MMP-2 and post-aneurysm MMP-2 and -9 levels were higher in 129/ SvEv aortas compared to C57Bl/6 aortas. Elastic lamella disruption/fragmentation and macrophage infiltration were increased in 129/SvEv mice. Myelogenous cell reversal by bone marrow transplantation did not affect aneurysm size.

Conclusions: These data demonstrate that $129 / \mathrm{SvEv}$ mice are more susceptible to AAA compared to $\mathrm{C} 57 \mathrm{Bl} / 6 \mathrm{mice}$. Intrinsic properties of the aorta between the two strains of mice, including baseline expression of MMP-2, influence susceptibility to AAA.
\end{abstract}

Keywords: Aneurysm, Matrix metalloproteinase, Aorta

Abbreviations: AAA = abdominal aortic aneurysm; MFS = Marfan syndrome; MMP = matrix metalloproteinase; VVG = Verhoeff-Van Gieson

\section{Introduction}

The incidence of abdominal aortic aneurysm (AAA) ranges from 2 to $3 \%$ in the general population with an increasing incidence of $4-9 \%$ in men over the age of 60 reported [1,2]. The pathogenesis of AAA remains obscure and the treatment is still mechanical. Studies of human aortic aneurysm tissue obtained at surgery are informative but likely reflect the end stage of the disease process. To investigate the cause of aneurysmal disease and to determine early pathophysiological changes in AAA, animal models are commonly used. Studies with animal models have led to advances including recognition that chronic inflammation, increased expression of endogenous proteinases, degradation of structural matrix proteins, and medial smooth muscle cell depletion all play a role in the process of aneurysm development $[3,4]$. Genetically engineered mice have been increasingly used to investigate the molecular mechanisms of AAA. Important insights pertaining to inflammatory cytokines and matrix 
metalloproteinases (MMPs) have been obtained from mouse studies involving targeted disruptions of genes such as interferon$\mathrm{g}$, tumor necrosis factor-a, MMP-2 and -9 [5-8]. Abundant evidence has demonstrated the profound influence of genetic background on cardiovascular phenotypes [9-12]. Although a single gene mutation has not been found in association with most AAAs, a positive family history of AAA in a first degree relative is known to increase the risk of aortic aneurysm by up to a factor of ten [13]. Attempts to define the genetic component(s) underlying AAA have used a variety of strategies, including both linkage analysis and candidate gene approaches [14]; nonetheless, a consensus on the patterns of inheritance or specific linkages associated with AAA has yet to emerge.

A variety of different mouse strains have been used to assess aortic aneurysms [15-19]. The most widely used parent strains for the production of mutants in aneurysm research are $\mathrm{C} 57 \mathrm{Bl} / 6$ and $129 / \mathrm{SvEv}$ mice $[7,8,20]$. In contrast to AAA, thoracic aortic aneurysms are associated with a number of known genetic mutations. Marfan syndrome (MFS) is caused by fibrillin-1 gene mutations that are responsible for thoracic aneurysm development [21]. Studies of animal models of MFS have shown that genetic background-related variations, $\mathrm{C} 57 \mathrm{Bl} / 6$ or $129 / \mathrm{SvEv}$, affect aneurysm formation, rupture, and lifespan of mice [20,22]. The 129/ $\mathrm{SvEv}$ genetic background is associated with more rapid aneurysm progression in MFS mice when compared to the $\mathrm{C} 57 \mathrm{Bl} / 6$ background [20]. As in AAA, higher MMP-2 expression in the aorta of Marfan syndrome mice plays an important role in aneurysm formation [21]. Therefore, the variance of thoracic aneurysm susceptibility in MFS could also be informative regarding the underlying genetic susceptibility to AAA. In reviewing our previous studies, we noted that $129 / \mathrm{SvEv}$ mice also developed larger AAAs compared to $\mathrm{C} 57 \mathrm{Bl} / 6$ mice in response to $\mathrm{CaCl}_{2}$-aneurysm induction [7]. Based on these observations, we hypothesized that the difference seen in aneurysm susceptibility between the two genetic backgrounds is related to intrinsic differences in smooth muscle cell MMP-2 or macrophage MMP-9 expression [7].

\section{Materials and methods}

\subsection{Animal aneurysm model}

All procedures and animal studies were approved by the University of Nebraska Medical Center IACUC. The experimental groups consisted of 24 eight weeks-old male $\mathrm{C} 57 \mathrm{Bl} / 6$ mice (The Jackson Laboratory, Bar Harbor, Maine) and 20 eight weeks-old male 129/SvEv mice (Taconic, Germantown, New York). Mice were anesthetized and underwent laparotomy. The abdominal aorta between the renal arteries and bifurcation of the iliac arteries was isolated from the surrounding retroperitoneal structures. The diameter of the aorta was measured using a Leica Application System (Leica Microsystems Inc, Buffalo Grove, IL). After baseline measurements, $0.25 \mathrm{M} \mathrm{CaCl}_{2}$ was applied to the aorta with care taken to avoid surrounding tissue. After $15 \mathrm{~min}$ the aortawas rinsed with $0.9 \%$ sterile saline, the laparotomy incision was closed, and mice were returned to their cages after recovery. Six weeks later the mice underwent repeat laparotomy, dissection, and measurement of the aorta. Aortic diameter was measured at the point of maximal dilatation. The aorta tissue was collected for zymographic and Western blot analyses. For histological studies, the aorta was perfusion-fixed with $10 \%$ neutral buffered formalin. $\mathrm{NaCl}(0.9 \%)$ was substituted for $\mathrm{CaCl}^{2}$ in sham controls.

\subsection{Isolation and infusion of myelogeous cells}

To evaluate the role of the myelogenous cells on aneurysm sus- ceptibility, 6 week-old C57Bl/6 or 129/SvEv mice were irradiated $(1200 \mathrm{rad})$ and transplanted with bone marrow from $129 / \mathrm{SvEv}$ (designated as $\mathrm{C} 57^{\mathrm{bkg}} / \mathrm{SvEv}{ }^{\mathrm{bm}}$ mice) or $\mathrm{C} 57 \mathrm{Bl} / 6$ mice $\mathrm{SvEv}^{\mathrm{bkg} /}$ $\mathrm{C} 57^{\mathrm{bm}}$ mice), respectively. As controls, we also transplanted bone marrow from $\mathrm{C} 57 \mathrm{Bl} / 6$ or $129 / \mathrm{SvEv}$ mice into the irradiated, same background mice, C57Bl/6 (designated as C57 $\mathrm{bkg} / \mathrm{C} 57^{\mathrm{bm}}$ ) or $129 /$ $\mathrm{SvEv}\left(\mathrm{SvEv}^{\mathrm{bkg}} / \mathrm{SvEv}^{\mathrm{bm}}\right)$, respectively. We have previously demonstrated that this radiation protocol results in bone marrow ablation and is fatal without rescue by bone marrow transplantation [23]. Bone marrow cell suspensions were prepared from the femurs of $\mathrm{C} 57 \mathrm{Bl} / 6$ or $129 / \mathrm{SvEv}$ mice, and 5 _ $10^{6}$ cells were infused via the lateral tail veins. Aneurysm induction followed 1 week after bone marrow transplantation.

\subsection{Western blot analysis and gelatin zymography}

Aortic proteins were extracted as previously described [21]. The protein concentration of aortic tissues was standardized with a Bio- Rad protein assay. Equal amounts $(10 \mathrm{mg})$ of aortic extracts were loaded under reducing conditions onto a $10 \%$ SDS-polyacrylamide gel and transferred to a polyvinylidene difluoride (PVDF) membrane (Amersham Biosciences, Piscataway, NJ). The membranes were then incubated with rabbit anti-tropoelastin antibody (Elastin Products Company, Owensville, MO) or rabbit anti-collagen1a antibody (Cell Signaling, Danvers, MA). The bound primary antibody was detected with HRP-linked antirabbit IgG (Cell Signaling). Immunoreactive bands were visualized by autoradiography using ECL (Amersham Biosciences). Gelatin zymography for aortic tissue extracts was performed as described previously by Longo et al., with $0.8 \%$ gelatin in a $10 \%$ SDS-polyacrylamide gel [7]. The molecular sizes were determined using protein standards from Fermentas (Glen Burnie, MD). The intensity of each band was quantified by densitometry (Amersham Biosciences).

\subsection{Microscopy}

1) Verhoeff-Van Gieson (VVG) connective tissue staining: After perfusion-fixation with $10 \%$ neutral-buffered formalin, mouse abdominal aortic tissues were embedded in paraffin and cut into $4 \mathrm{~mm}$ sections. The slides were stained with Verhoeff's solution, ferric chloride, sodium thiosulfate, and Van Gieson's solution (Poly Scientific, Bay Shore, NY). Each staining cycle alternated between fixing and washing procedures. The slides were examined and photographed using light microscopy (Nikon). 2) Quantification of Elastin Disruption: Slides of both $\mathrm{CaCl}^{2}$. treated $\mathrm{C} 57 \mathrm{Bl} / 6$ and $129 / \mathrm{SvEv}$ mice were examined under low power magnification. A semiquantitative analysis was used to estimate the percentage of the total circumference that demonstrated elastin disruption. The analysis was performed by an observer blinded to mouse background. 3) Immunohistochemistry: Tissue sections on the slides were deparaffinized in xylene, rehydrated in ethanol, and rinsed in double-distilled water. The sections were incubated with a monoclonal rat anti-mouse Mac3 antibody (PharMingen, San Diego, CA) diluted 1:500 for $30 \mathrm{~min}$ at 37 -C. The sections were then briefly washed in citrate solution and subsequently incubated with the secondary antibody, which is a mouse-absorbed, biotin-conjugated rabbit anti-rat IgG. Macrophage staining was examined using light microscopy. Sections incubated with secondary antibody only showed no positive staining. Three samples in each mouse strain were stained and evaluated.

\subsection{Elastic modulus measurement}

Quasi-static nanoindentation tests were performed on mouse aortas using a commercial TriboScope nanoindenter with a light 
microscope mounted (Hysitron, Minneapolis, MN). A nonporous conospherical fluid cell probe (TI-0077) with a radius of curvature of $R=100$ mmwas chosen. A custom-built sample holder was used to hold sample and ensure its hydration during indentation test. The optical images obtained from the microscope will guide the movementt of the indenter and allow accurate control on the indentation positions.

A trapezoidal load-hold-unload profile, which was composed of a linear loading portion of $2 \mathrm{~s}$, a dwell portion of $20 \mathrm{~s}$ at a predetermined peak load and a linear unloading portion of $2 \mathrm{~s}$, was used for each indentation. All samples were tested at peak load of $5 \mathrm{mN}$ during the dwell period. In total,16 indentations in a 4 _ 4 grid were conducted on each sample. The time interval between two indentations was $120 \mathrm{~s}$. The distance between two indentation pointswas $200 \mathrm{~mm}$. After indentations, the force-displacement data were collected. The elastic moduli of the specimens were obtained by fitting the force-displacement data to the Oliver-Pharr model.

\subsection{Elastase activity assay}

Elastase activity in the aortic extract $(100 \mathrm{mg})$ from $\mathrm{NaCl}-$ and $\mathrm{CaCl}^{2}$-treated $\mathrm{C} 57 \mathrm{Bl} / 6$ and $129 / \mathrm{SvEv}$ mice were measured using an elastase assay kit (AnaSpec, Fremont, CA) with and without
$10 \mathrm{mM}$ EDTA according to manufacturer instructions. Neutrophil elastase gene expression in the aortic tissue of $\mathrm{NaCl}-$ and $\mathrm{CaCl}^{2}$-treated $\mathrm{C} 57 \mathrm{Bl} / 6$ and $129 / \mathrm{SvEv}$ mice were examined by RTPCR as described previously [6].

\subsection{Statistical analysis}

Measurements of aortic diameter, elastin levels, and elastic moduli were expressed as mean value \pm S.D. ANOVA was used to compare aortic diameters. Student's t test was used to compare protein expression, MMP activity, and elastic moduli in different groups. Statistical significance was accepted at the $\mathrm{P}<.05$ levels.

\section{Experimental results}

\subsection{Aneurysm size and histology}

To test the hypothesis that genetic influences contribute to susceptibility of aneurysm formation, 129/SvEv and C57Bl/6 mice were subjected to $\mathrm{CaCl}^{2}$-aneurysm induction. Six weeks after periaortic application of $\mathrm{CaCl}^{2}, 129 / \mathrm{SvEv}$ mice showed a larger increase in abdominal aortic diameter compared to $\mathrm{C} 57 \mathrm{Bl} / 6$ mice (Figure 1a, b-e and Table 1). The initial aortic diameter
Figure 1. Aortic changes after $\mathrm{NaCl}$ and $\mathrm{CaCl}_{2}$ treatment in C57BI/ 6 and 129 /SvEv mice Aortic diameters were measured before $\mathrm{NaCl}$ or $\mathrm{CaCl}_{2}$ incubation and at sacrifice. Aortic diameter increases are shown in the bar graph (a). Bars represent the mean \pm SD of at least 6 mice per group. The diameter in the $\mathrm{CaCl}_{2}$ treated groups was increased significantly at sacrifice in both C57BI/6 and 129/SvEv mice compared to $\mathrm{NaCl}$ treated mice $(* P<$ .01). The aortic dilatation in $\mathrm{CaCl}_{2}$ treated 129/SvEv mice was significantly greater compared to $\mathrm{CaCl}_{2}$-treated $\mathrm{C57BI} / 6$ mice (\#P $<.05)$. Photographs (b-e) show the mouse aortas in C57BI/6 and $129 /$ SvEv mice with the dotted line indicating the outer border of the aortas before (b, c) and after $(\mathbf{d}, \mathbf{e}) \mathrm{CaCl}_{2}$ aneurysm induction, respectively, $(n=6-10 /$ group). VVG staining for elastic fibers (f-m). Aortic lamellae disruption (10x magnification) (h, i) and elastic fiber fragmentation (40x magnification) $(I, m)$ were more severe in $129 / \mathrm{SvEv}(\mathbf{i}, \mathbf{m})$ than in $\mathrm{C} 57 \mathrm{BI} / 6(\mathrm{~h}, \mathrm{l})$ mice $(n=$ 3-5/group). $n$, percentage of aortic circumference showing elastin disruption in $\mathrm{CaCl}_{2}$-treated C57BI/ 6 and 129/SvEv mice $(n=3$ aortas/group). a

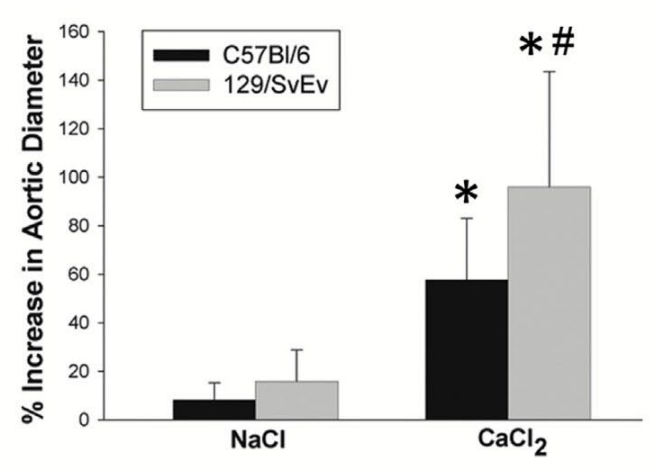

n
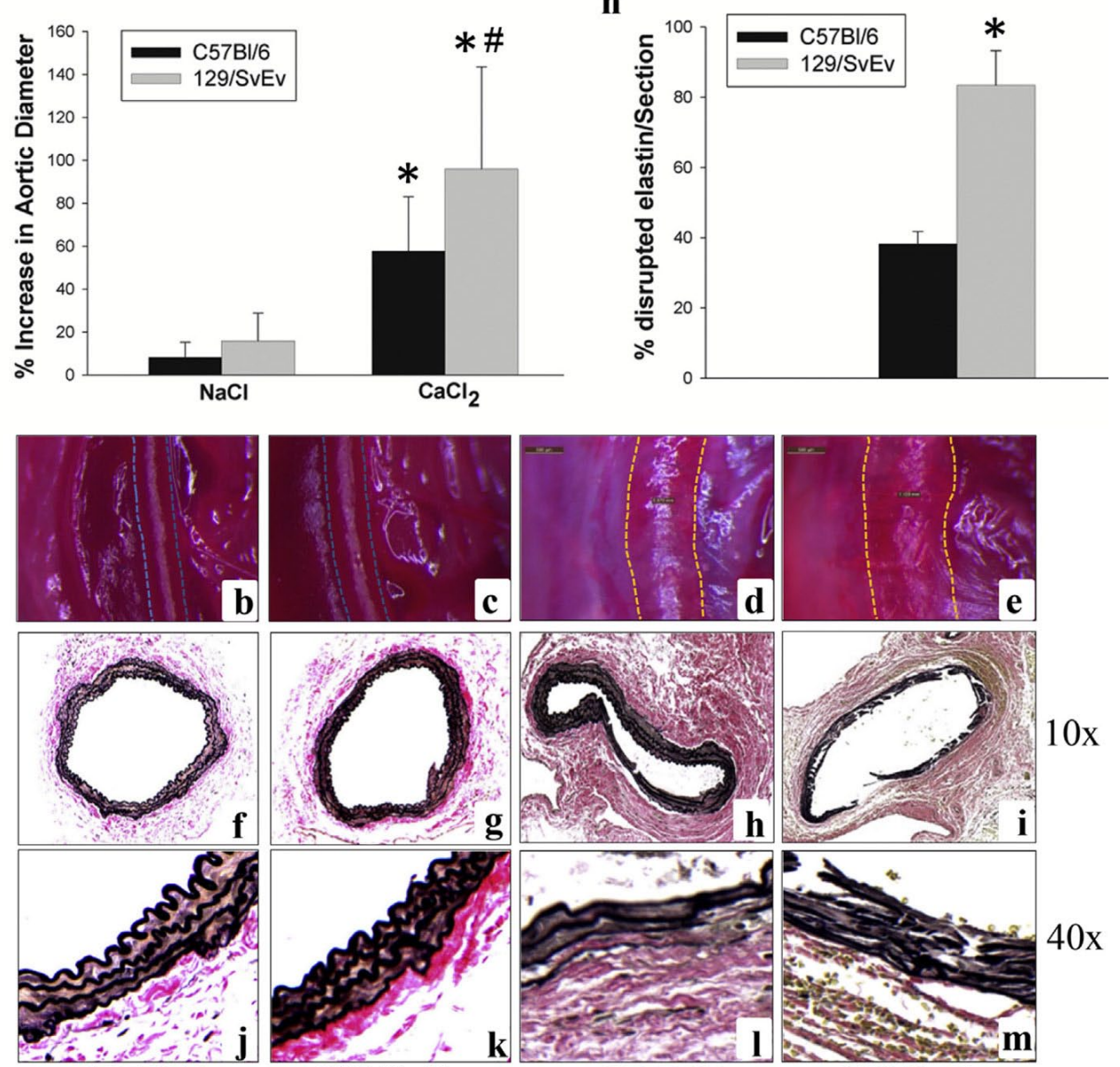

$\mathrm{C57BI} / 6$
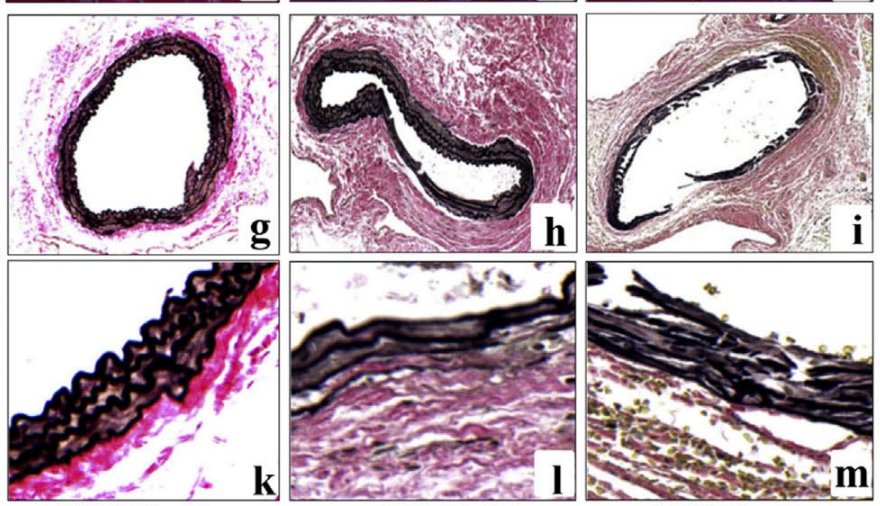

$10 \mathrm{x}$

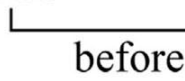

C57BI/6

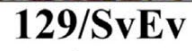

129/SvEv 
Table 1. Changes in aortic diameter in C57BI/6 and 129/SvEv mice after treatment of $\mathrm{NaCl}$ and $\mathrm{CaCl}_{2}$.

\begin{tabular}{|c|c|c|c|c|}
\hline \multirow[t]{2}{*}{ Treatment } & \multicolumn{2}{|l|}{$\mathrm{C} 57 \mathrm{BI} / 6$} & \multicolumn{2}{|l|}{ 129/SvEv } \\
\hline & $\mathrm{NaCl}$ & $\mathrm{CaCl}_{2}$ & $\mathrm{NaCl}$ & $\mathrm{CaCl}_{2}$ \\
\hline Number & 8 & 16 & 6 & 12 \\
\hline Pre-treatment (mm) & $520 \pm 14$ & $507 \pm 7$ & $544 \pm 15$ & $550 \pm 17$ \\
\hline Post-treatment (mm) & $562 \pm 17$ & $797 \pm 30^{*}$ & $628 \pm 18$ & $1067 \pm 67^{* \#}$ \\
\hline AAA development (\%) & 056 & 083 & & \\
\hline Percent increase (\%) & 8.3 & 57.81 & 5.9 & 96.3 \\
\hline
\end{tabular}

Aortic diameters were measured before $\mathrm{NaCl}$ or $\mathrm{CaCl}_{2}$ incubation (Pre) and at sacrifice (Post). Measurements of aortic diameter were expressed as mean \pm SE. The percent of increase was represented as a percent compared with pre-treatment. The development of aneurysm was defined as at least a $50 \%$ increase relative to original aortic diameter. ${ }^{*} P<.01$, Student's t test, compared to pre-treatment; $\# P<.05$ compared to $\mathrm{CaCl}_{2}$-treated $\mathrm{C} 57 \mathrm{BI} / 6$.

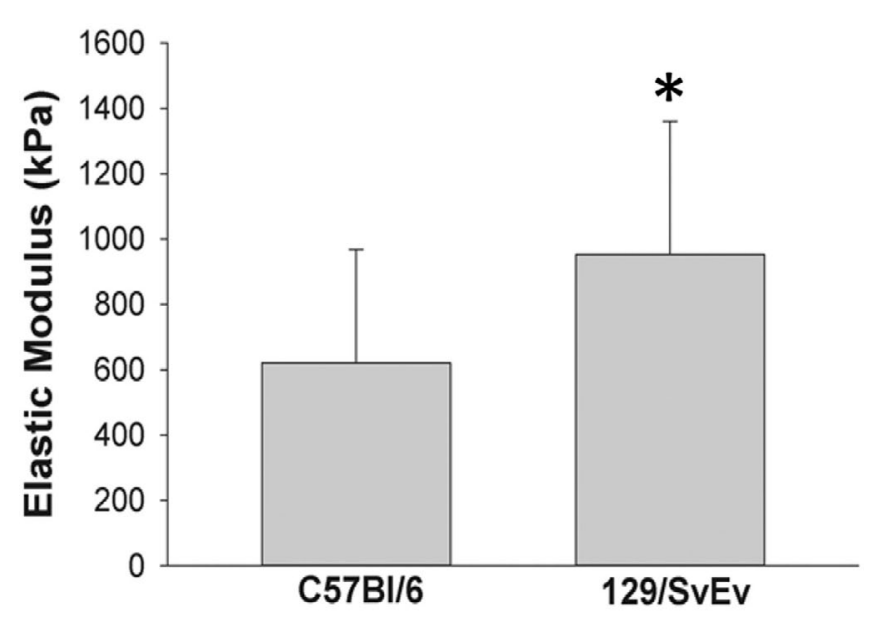

Figure 2. Elastic modulus of aortic tissues from C57BI/ 6 and $129 / \mathrm{SvEv}$ mice Prior to aneurysm induction, quasi-static nanoindentation tests were performed on the aortas and the elastic modulus was determined ( $n=3$ per group, $* P<.05)$. between two strains was not significantly different. At baseline, VVG staining of aortic sections from C57Bl/6 and 129/SvEv mice showed no difference (Figure 1f, g, j, k) while both showed disruption and fragmentation of medial elastic lamellae after aneurysm induction (Figure 1h, i, l, m). However, aortic elastic lamellae degradation appeared to be more severe in $129 / \mathrm{SvEv}$ mice (Figure $1 \mathrm{i}$ and $\mathrm{m}$ ) compared to $\mathrm{C} 57 \mathrm{Bl} / 6$ mice (Figure $1 \mathrm{~h}$ and $\mathrm{l}$ ). These observations are consistent with the larger aneurysms that develop in the $129 / \mathrm{SvEv}$ mice.

\subsection{Aortic elastic moduli}

The elastic lamella, which is comprised of elastic fibers, collagens, proteoglycans, and glycosaminoglycans, determines the biomechanical properties of the aorta. To test the hypothesis that baseline aortic mechanical properties of $\mathrm{C} 57 \mathrm{Bl} / 6$ mice differed from 129/SvEv mice, quasi-static nanoindentation tests were performed on the aortas isolated from the two strains of mice. The elastic moduli of the specimens were obtained by fitting the forcedisplacement data to the Oliver-Pharr model. The elastic moduli of C57Bl/6 mice were significantly less than that of the 129/ SvEv mice (Figure 2). Thus, the aortic wall in 129/SvEv mice was stiffer or less compliant than in the $\mathrm{C} 57 \mathrm{Bl} / 6$ mice.

\subsection{Aortic tropoelastin content}

Matrix synthesis is known to accompany the matrix degradation seen in AAA. Production of tropoelastin, the precursor molecule that becomes incorporated into mature elastin fibers, in the aneurysmal aortas was examined by Western blot analysis. At baseline, therewas no different in tropoelastin production between two strains (Figure 3a). The tropoelastin levels in $\mathrm{CaCl}^{2}$-treated aortas of $129 / \mathrm{SvEv}$ mice were decreased by one third compared to $\mathrm{CaCl}^{2}$ - treated aortas of $\mathrm{C} 57 \mathrm{Bl} / 6$ mice (Figure $3 \mathrm{~b})$. The procollagen 1a levels in the aortas were also examined byWestern blot analysis. There was no difference in procollagen 1a content between the two strains of mice (data not shown). These data suggest that the $129 / \mathrm{SvEv}$ mice may be less able to repair elastin once it has been disrupted.

\section{a. Untreated control}

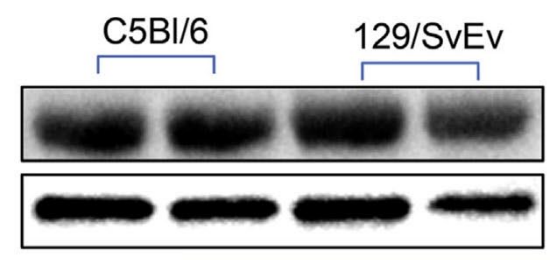

\section{b. $\mathrm{CaCl}_{2}$-treated}

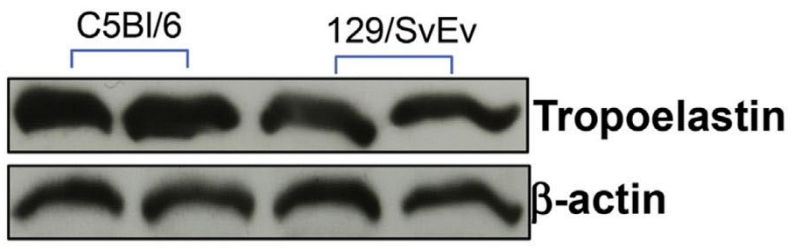

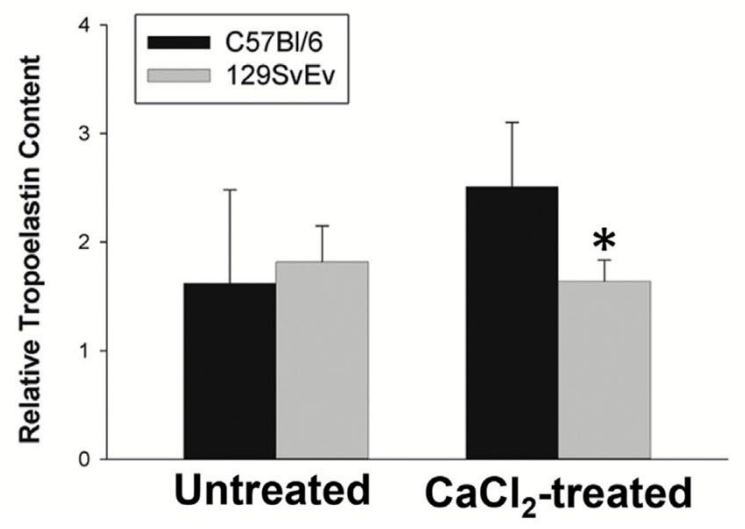

Figure 3. Aortic tropoelastin content Western blot analysis was used to determine tropoelastin content from C57BI/ 6 and 129/SvEv mice before (a) and after (b) AAA induction. Relative levels of tropoelastin content in mouse aortas were quantified as shown in bar graphs ( ${ }^{*} P<.05$ compared to $\mathrm{CaCl}_{2}$ treated $\mathrm{C} 57 \mathrm{BI} / 6$ mice) ( $n=$ 5-7/group). 


\subsection{Aortic MMP-2 and MMP-9 expression}

MMP-2 and MMP-9 are essential for the connective tissue degradation in the aortic wall leading to AAA [7]. Because the greater level of elastin degradation in the 129/SvEv mice suggests higher levels of MMP activity, we determined if the aortas from C57Bl/6 and 129/SvEv mice expressed different levels of MMP-2 and MMP-9 at baseline and after aneurysm induction. Aortic protein was analyzed by gelatin zymography. As shown in Figure 4a, latent MMP-2 expression in untreated 129/SvEv mice was significantly higher than in untreated $\mathrm{C} 57 \mathrm{Bl} / 6$ mice. Furthermore, after aneurysm induction, active forms of MMP-2 and MMP-9 were higher in the aortas of $129 / \mathrm{SvEv}$ mice (Figure $4 \mathrm{~b}$ ). These results demonstrated that $129 / \mathrm{SvEv}$ mice express higher levels of pro- MMP-2 intrinsically. Additionally, after aortic injury, there is greater activation of MMP-2 and MMP-9 in 129/SvEv mice. Increased MMP-9 expression in aortic tissues after aneurysm induction may indicate higher levels of MMP-9 expression from macrophages or increased macrophage infiltration into the aortic tissue in $129 / \mathrm{SvEv}$ mice compared to $\mathrm{C} 57 \mathrm{Bl} / 6$ in response to $\mathrm{CaCl}^{2}$ treatment. Therefore, aortic tissues were examined for the presence of Mac3-positive macrophages. The images obtained suggested greater macrophage infiltration in the 129/SvEv mice aortas compared to C57Bl/6 mice (Figure 4c and Table 2). These results suggest intrinsic differences in mesenchymal cell MMP-2 levels and also differences in response to injury.

\subsection{Aortic elastase activity}

In addition to MMP-2 and -9, other elastases could be responsible for the elastin degradation in AAA. We measured elastase activity in the aortic tissue from $\mathrm{C} 57 \mathrm{Bl} / 6$ and 129/SvEv mice. Elastolytic activity was similar between $\mathrm{NaCl}$-treated $\mathrm{C} 57 \mathrm{Bl} / 6$ and 129/ SvEv mice (Figure 5a). However, elastase activity in $\mathrm{CaCl}^{2}$-treated 129/ $\mathrm{SvEv}$ and $\mathrm{C} 57 \mathrm{Bl} / 6$ mice was significantly higher than $\mathrm{NaCl}$-treated 129/SvEv or C57Bl/6, respectively (Figure 5a). Furthermore, compared to $\mathrm{CaCl}^{2}$-treated $\mathrm{C} 57 \mathrm{Bl} / 6$ mice, elastolytic activity in $\mathrm{CaCl}^{2}$-treated $129 / \mathrm{SvEv}$ was higher (Figure 5a). Neutrophils play an important role in aneurysm formation [24,25]. We also tested neutrophil elastase gene expression using RT-PCR. We found that there were no significant

Table 2. The number of macrophages in the $\mathrm{CaCl}_{2}$-treated aorta of 129/SvEv and C57BI/6 mice.

\begin{tabular}{lc}
\hline & Mouse strain macrophages \\
\hline $129 / \mathrm{SvEv}$ & $2.3 \pm 0.6^{*}$ \\
$\mathrm{C} 57 \mathrm{BI} / 6$ & $1.0 \pm 0.5$ \\
\hline
\end{tabular}

Macrophages in aorta were evaluated and scored with values from 0 to 3 . Zero means no Mac3-positive cells and 3 means many cells in a limited area, the values 1 and 2 are used to classify intermediate grades of infiltration. The values reflect the mean $\pm \mathrm{SD}$. ${ }^{*} P=.0390$, Student's $t$ test. $n=3$.

\section{a. Untreated control}
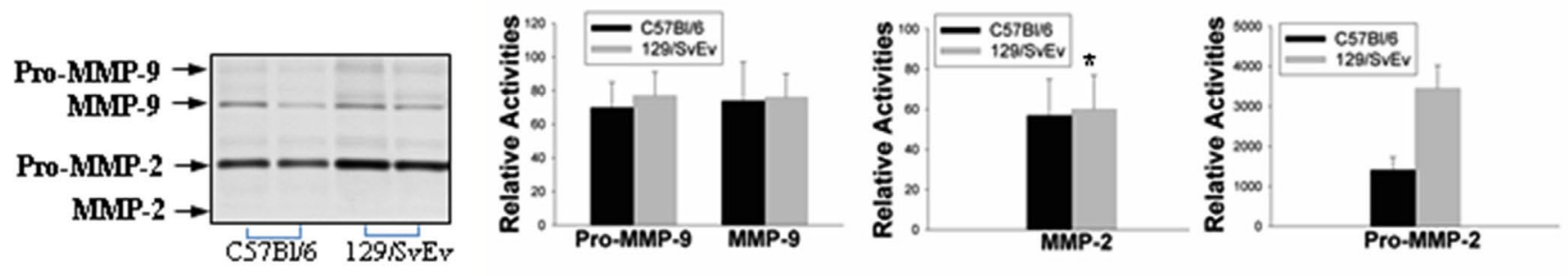

\section{b. $\mathrm{CaCl}_{2}$-treated}
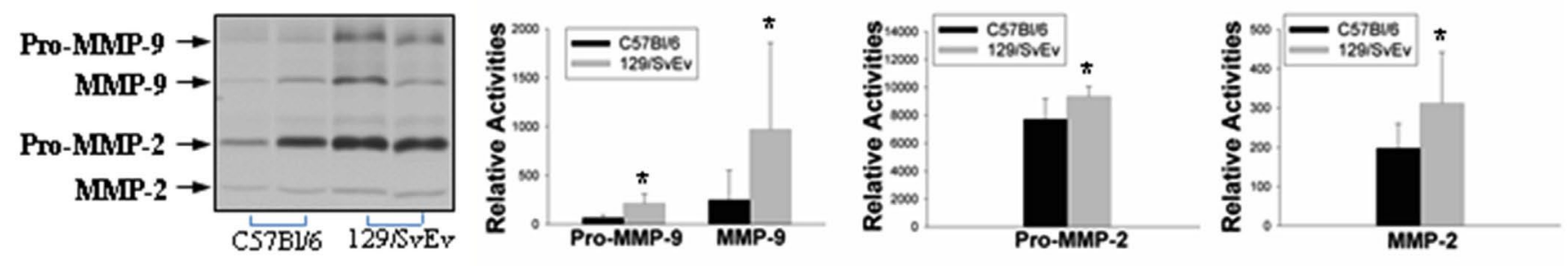

c
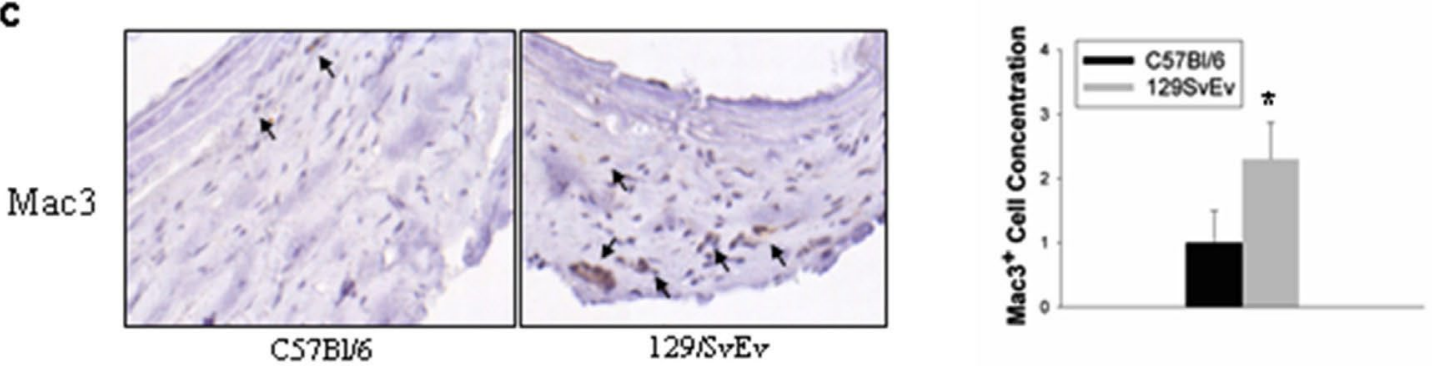

Figure 4. Aortic MMP-2 and MMP-9 expression Gelatin zymography analysis of MMP activities expressed in the aortas of C57BI/6 and 129/SvEv mice, a) Untreated controls; b) $\mathrm{CaCl}_{2}$ - treated mice. Representative zymogram gels are shown in left panels. Relative levels of pro-MMP-9, MMP-9, pro-MMP-2, MMP-2 in mouse aortas were quantified and data shown in the bar graphs $\left({ }^{*} P<.05\right)$. c) Macrophages in aortic tissue were evaluated and scored with values from 0-3 as previously described (7). Zero indicates that there were no Mac3-positive cells, 3 indicated many Mac3-positive cells in a limited area, and 1 and 2 were used to classify intermediate grades of Mac3-positive cells $(n=3 / g r o u p)$. Representative immunoperoxidase staining for macrophages of aneurysmal aortic tissues from C57BI/6 and 129/SvEv mice. Mac3-positive cells are indicated by arrows. 


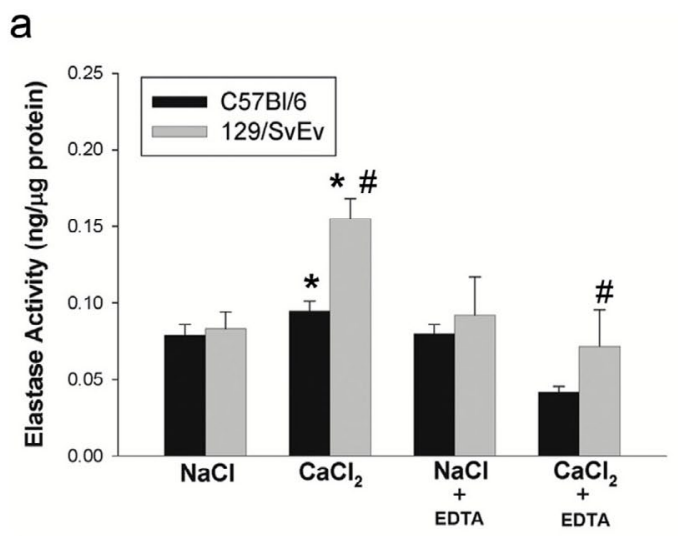

b

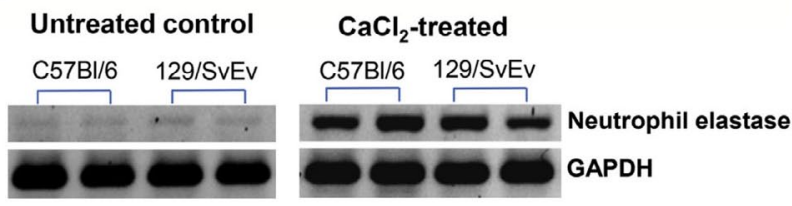

C

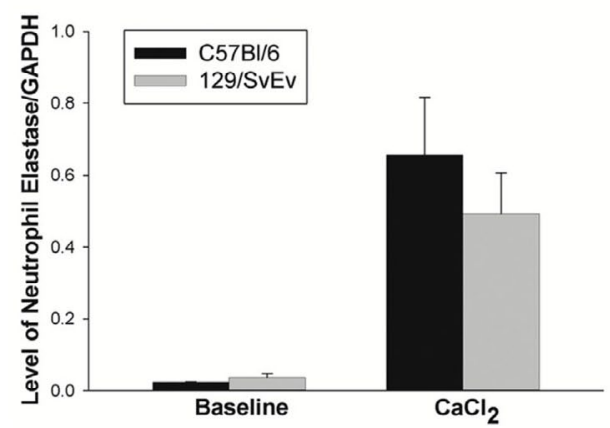

Figure 5. Aortic elastase activity and neutrophil elastase expression a) Elastase activity in aortic tissue extract from $\mathrm{C} 57 \mathrm{BI} / 6$ and $129 / \mathrm{SvEv}$ mice was measured, ( ${ }^{*} P<.05$ compared to $\mathrm{NaCl}$-treated control, \#P $<.05$ compared to $\mathrm{CaCl}_{2}$-treated $\mathrm{C} 57 \mathrm{BI} / 6$ mice) ( $\mathrm{n}=3 /$ group). EDTA was used to block MMP activity. b) The neutrophil elastase expression in the aortas of C57BI/ 6 and 129/SvEv mice was examined by RTPCR; untreated controls (left panel) and $\mathrm{CaCl}_{2}$-treated mice (right panel). c) The levels of neutrophil elastase mRNA relative to GAPDH in the aorta were quantified; data shown in the bar graphs ( $n=3$ /group).

differences between $\mathrm{C} 57 \mathrm{Bl} / 6$ and 129/ SvEv mice at baseline or in aneurysmal aortic tissue (Figure $5 \mathrm{~b}$ and c). In order to determine the contribution of MMPs, EDTA was used to block MMP activity prior to measuring total elastolytic activity (Figure 5a). These data demonstrated that the majority of enhanced activity was due to increased elastin degradation by MMPs.

\subsection{Role of myelogenous cells in AAA susceptibility}

The known role of inflammatory cells in AAA and differences in the levels of active MMP-9 in the C57Bl/ 6 and the $129 / \mathrm{SvEv}$ mice suggested that there could be intrinsic differences in the myelogenous cells. In order to investigate this, $\mathrm{C} 57 \mathrm{Bl} / 6$ derived bone marrow cells were infused into irradiated 129/

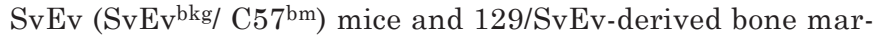
rowcells were infused into irradiated $\mathrm{C} 57 \mathrm{Bl} / 6\left(\mathrm{C} 57^{\mathrm{bkg}} / \mathrm{SvEv}{ }^{\mathrm{bm}}\right)$ mice. As controls, we also transplanted bone marrow from $\mathrm{C} 57 \mathrm{Bl} / 6$ or $129 / \mathrm{SvEv}$ mice into the irradiated, same background mice, $\mathrm{C} 57 \mathrm{Bl} / 6\left(\mathrm{C} 57^{\mathrm{bkg}} / \mathrm{C} 57^{\mathrm{bm}}\right)$ or $129 / \mathrm{SvEv}\left(\mathrm{SvEv}^{\mathrm{bkg}} / \mathrm{SvEv}^{\mathrm{bm}}\right)$, a

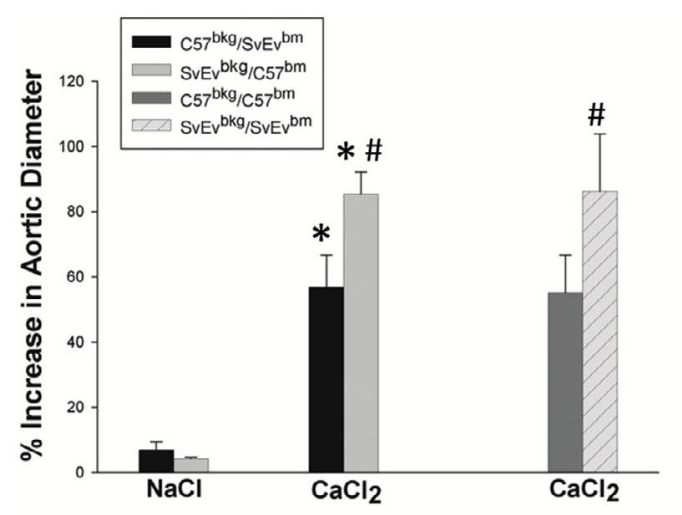

b

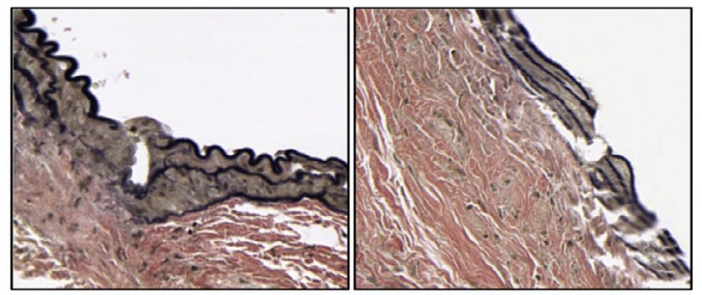

$\mathrm{C} 57^{\mathrm{bkg}} / \mathrm{SvEv}{ }^{\mathrm{bm}}$

SvEv ${ }^{\mathrm{bkg}} / \mathrm{C} 57^{\mathrm{bm}}$

C

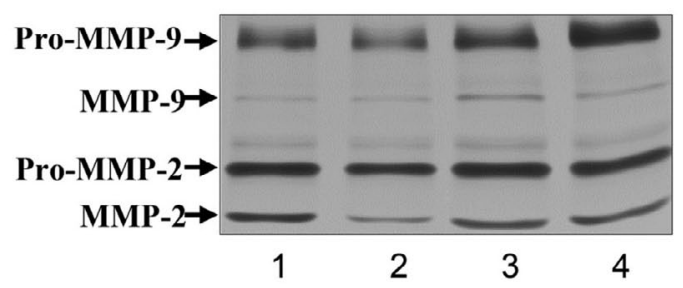

Figure 6. The role of myelogenous cells in AAA susceptibility The chimeric mice, C57bkg/C57bm, SvEvbkg/SvEvbm, C57bkg/SvEvbm, and SvEvbkg/C57bm, were subjected to $\mathrm{CaCl}_{2}$ aneurysm induction. Aortic diameter changes were shown in the bar graph (a) $\left({ }^{*} P<.01 \mathrm{com}-\right.$ pared to $\mathrm{NaCl}$ control; \#P<.05 C57bkg/SvEvbm vs. SvEvbkg/C57bm and $\mathrm{C} 57 \mathrm{bkg} / \mathrm{C} 57 \mathrm{bm}$ vs. SvEvbkg/SvEvbm after $\mathrm{CaCl}_{2}$ treatment). Bars represent the mean \pm SD of 6 mice per group. Representative VVG staining of elastic fibers after aneurysm induction (b). Gelatin zymography of aortic MMP-2 and -9 levels in $\mathrm{CaCl}_{2}$-treated $\mathrm{C} 57 \mathrm{bkg} / \mathrm{C} 57 \mathrm{bm}$ (lane 1), C57bkg/SvEvbm (lane 2), SvEvbkg/SvEvbm (lane 3), and SvEvbkg/C57bm (lane 4) (c).

respectively. The chimeric mice were subjected to $\mathrm{CaCl}^{2}$-aneurysm induction. Six weeks after aneurysm induction, $\mathrm{SvEv}^{\mathrm{bkg} /}$ C5 $7^{\mathrm{bm}}$ developed larger aneurysms than the $\mathrm{C} 57^{\mathrm{bkg}} / \mathrm{SvEv}{ }^{\mathrm{bm}}$ (Figure 6a). Aortic diameter in the $\mathrm{SvEv}{ }^{\mathrm{bkg}} / \mathrm{C} 57^{\mathrm{bm}}$ increased by $85 \% \pm 4$, while the $\mathrm{C} 57^{\mathrm{bkg}} / \mathrm{SvEv}^{\mathrm{bm}}$ increased by $56 \% \pm 6$ (Table 3). The aortic diameter changes in $\mathrm{C} 57^{\mathrm{bkg}} / \mathrm{C} 57^{\mathrm{bm}}$ and $\mathrm{SvEv}{ }^{\mathrm{bkg}} / \mathrm{SvEv}{ }^{\mathrm{bm}}$ were similar to $\mathrm{C} 57^{\mathrm{bkg}} / \mathrm{SvEv}^{\mathrm{bm}}$ and $\mathrm{SvEv}{ }^{\mathrm{bkg}} /$ $\mathrm{C} 57^{\mathrm{bm}}$, respectively. Furthermore, the disruption of the elastic lamellae of the aortic wall of $\mathrm{CaCl}^{2}$-treated $\mathrm{C} 57^{\mathrm{bkg}} / \mathrm{SvEv}^{\mathrm{bm}}$ was less severe than the $\mathrm{SvEv}{ }^{\mathrm{bkg}} / \mathrm{C} 57^{\mathrm{bm}}$ chimeric mice (Figure $6 \mathrm{~b}$ ). Aortic MMP-2 and MMP-9 levels in C5 $7^{\mathrm{bkg}} / \mathrm{SvEv}{ }^{\mathrm{bm}}$ mice were lower than in $\mathrm{SvEv} v^{\mathrm{bkg}} / \mathrm{C} 57^{\mathrm{bm}}$ mice while it is similar between $\mathrm{C} 57^{\mathrm{bkg}} / \mathrm{C} 57^{\mathrm{bm}}$ and $\mathrm{C} 57^{\mathrm{bkg}} / \mathrm{SvEv} v^{\mathrm{bm}}$ and between $\mathrm{SvEv}{ }^{\mathrm{bkg}} / \mathrm{SvEv}{ }^{\mathrm{bm}}$ and $\mathrm{SvEv} v^{\mathrm{bkg}} / \mathrm{C} 57^{\mathrm{bm}}$ (Figure 6c). The changes in aortic diameter in the chimeric mice were very similar in magnitude to the differences noted when the background strains were compared. These data do not support the concept that differences in the white cell compartments account for differences in aneurysm susceptibility. 
Table 3. Changes in aortic diameter in chimeric mice after treatment of $\mathrm{NaCl}$ and $\mathrm{CaCl}_{2}$.

\begin{tabular}{|c|c|c|c|c|c|c|}
\hline \multirow[t]{2}{*}{ Treatment } & \multicolumn{2}{|c|}{$\mathrm{C} 57^{\mathrm{bkg}} / \mathrm{SvEv}{ }^{\mathrm{bm}}$} & \multicolumn{2}{|c|}{$\mathrm{SvEv}^{\mathrm{bkg}} / \mathrm{C} 57^{\mathrm{bm}}$} & \multirow{2}{*}{$\frac{\mathrm{C} 57^{\mathrm{bkg}} / \mathrm{C} 57^{\mathrm{bm}}}{\mathrm{CaCl}_{2}}$} & \multirow{2}{*}{$\frac{\mathrm{SvEv}^{\mathrm{bkg}} / \mathrm{SvEv}^{\mathrm{bm}}}{\mathrm{CaCl}_{2}}$} \\
\hline & $\mathrm{NaCl}$ & $\mathrm{CaCl}_{2}$ & $\mathrm{NaCl}$ & $\mathrm{CaCl}_{2}$ & & \\
\hline Number & 5 & 5 & 5 & 5 & 4 & 5 \\
\hline Post-treatment (mm) & $540 \pm 21$ & $837 \pm 48^{*}$ & $531 \pm 6$ & $945 \pm 71$ *\# & $779 \pm 48$ & $960 \pm 77 t$ \\
\hline AAA development (\%) & 0 & 60 & 0 & 100 & 50 & 100 \\
\hline Percent of increase (\%) & 7 & 57 & 4 & 85 & 55 & 86 \\
\hline
\end{tabular}

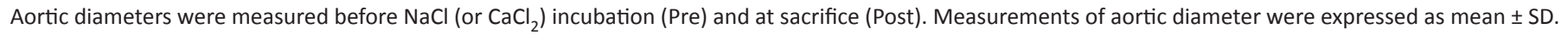
The percent of increase was represented as a percent compared with pre-treatment. The development of aneurysm was defined as at least $50 \%$ increase rela-

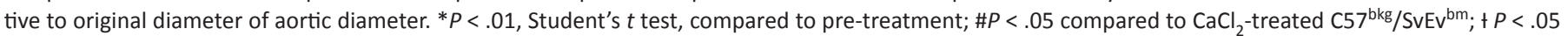
compared to $\mathrm{CaCl}_{2}$-treated $\mathrm{C} 57^{\mathrm{bkg}} / \mathrm{C} 57^{\mathrm{bm}}$.

\section{Discussion}

The majority of genomic studies used to identify susceptibility pathways involved in disease pathologies have been performed in the mouse [26-28]. The mouse provides a suitable model for the study of human genetics because more than $95 \%$ of the genome is identical. The mouse genome is easy to manipulate allowing diseases to be modeled in transgenic animals once the target genes have been determined. Mice are also easy to breed with a short generation time and a short lifespan allowing direct study of disease development. Abundant evidence, however, demonstrates the profound influence of genetic background on the course and severity of many diseases [29-31]. Strain variability has been shown to influence aneurysm formation, progression, and even lifespan in MFS mouse models. Lima et al. demonstrated the effect of genetic background on the severity of the MFS phenotype by backcrossing the $\mathrm{mg} \Delta$ allele, in which fibrillin- 1 expression is reduced to $10 \%$ of normal levels, in $129 / \mathrm{SvEv}$ and $\mathrm{C} 57 \mathrm{Bl} / 6$ mouse strains [20]. The 129/SvEv background was more susceptible to aneurysm formation and earlier aortic rupture. Increased susceptibility to aneurysm formation in the 129/SvEv background when compared to the $\mathrm{C} 57 \mathrm{Bl} / 6$ background was also present in the least severe model of MFS (Fbn $1^{\mathrm{C} 1039 \mathrm{G} /+} ; 50 \%$ normal fibrillin-1 expression levels). Clearly, the genetic differences between the two strains are relevant to thoracic aortic aneurysm pathogenesis. To determine whether the development of AAA is dependent on mouse genetic background, we induced aneurysms in two widely used mouse strains, C57Bl/6 and 129/SvEv. Mice from both genetic backgrounds displayed increased aortic diameters and developed aneurysms in response to $\mathrm{CaCl}^{2}$ induction, but the aneurysms formed in $129 / \mathrm{SvEv}$ mice were significantly larger compared to $\mathrm{C} 57 \mathrm{Bl} / 6$ mice. Compared to our previous study [7], the difference in $\mathrm{CaCl}^{2}$-treated aortic diameter between two strains was bigger in the present study. In previous study, the aneurysms in the two strains were not induced concurrently. In the present study, the aneurysms in two strains were induced simultaneously with one operator.We believe this better represents the differences between the two strains. In $\mathrm{NaCl}$-treated controls of $129 / \mathrm{SvEv}$ mice, the average increase in aortic diameter was larger than previous reported [7]. In the present study, we have used a camera having higher resolution to define the aortic borders. We believe this primarily reflects growth of the aorta between 7 and 14 weeks. Consistent with these differences in aneurysm size, aortic elastic lamellar disruption and degradation in $129 / \mathrm{SvEv}$ mice were more severe compared to $\mathrm{C} 57 \mathrm{Bl} / 6$ mice. Age and gender are also important factors in aneurysm development in patients with AAA. Mice of the same age and gender were used to exclude these as possible confounding factors.

Our current results, based on determination of the elastic modulus, demonstrate that the abdominal aortas of $129 / \mathrm{SvEv}$ mice were stiffer at baseline than those of $\mathrm{C} 57 \mathrm{Bl} / 6$ mice. There is indirect evidence that patients with AAAs may have a systemic increase in arterial stiffness. Dijk et al. have shown that the carotid artery is stiffer in AAA patients compared to control patients without AAA [32]. In order to determine if the differences in mechanical properties were related to intrinsic differences in gene expression, we examined aortic elastin and collagen precursor levels prior to aneurysm induction. C57Bl/6 and $129 / \mathrm{SvEv}$ mice express similar levels of tropoelastin and procollagen (data not shown). There is evidence that the elasticity of arterial wall may impact susceptibility to arterial diseases. Studies have shown that aortic elastin haploinsufficiency leads to high blood pressure and progressive aortic valve malformation $[33,34]$. We did not measure tail cuff blood pressure in the current study but other studies have demonstrated that 129/ SvEv mice have higher basal blood pressure than $\mathrm{C} 57 \mathrm{Bl} / 6$ mice and $129 / \mathrm{SvEv}$ mice are more likely to develop hypertension and renal damage than $\mathrm{C} 57 \mathrm{Bl} / 6$ mice in response to deoxycorticosterone acetate $[35,36]$. These results could occur because of baseline differences in mechanical properties or be the result of differences in response to exogenous stimuli. Currently, the association between hypertension and AAA remains unclear. It has been reported that in angiotensin II-infused $\mathrm{Apo}^{-}{ }^{-}-$mice, AAA formation is independent of blood pressure elevation [37-39]. We have previously demonstrated that there is an ongoing repair mechanism in patients with AAA as evidenced by high levels of collagen gene expression [40]. Six weeks after $\mathrm{CaCl}^{2}$-induction, tropoelastin levels in $129 / \mathrm{SvEv}$ mice were significantly lower than C57Bl/6 mice. Procollagen levels did not differ between the two strains after aneurysm induction (data not shown). Aneurysm susceptibility may be related to baseline differences in tissue properties. This difference would be exacerbated in the $129 / \mathrm{SvEv}$ because of the reduced ability to produce equivalent amounts of tropoelastin as is produced by $\mathrm{C} 57 \mathrm{Bl} / 6$.

Matrix metalloproteinases, especially MMP-2 and -9 , play important roles in aneurysm formation. Interestingly, 129/SvEv mice intrinsically produce higher amounts of latent MMP-2 in the aorta compared to $\mathrm{C} 57 \mathrm{Bl} / 6$ mice. This results in higher levels of active MMP-2 in 129/SvEv after $\mathrm{CaCl}^{2}$-treatment compared to $\mathrm{C} 57 \mathrm{Bl} / 6$. MMP-2 is primarily a product of resident aortic smooth muscle cells and fibroblasts. Initial degradation of elastin byMMP-2 may produce elastin fragments, which are known to induce monocyte chemotaxis [41,42]. This may account for the increased macrophage infiltrates seen in the aortas of 129/ SvEv mice compared to $\mathrm{C} 57 \mathrm{Bl} / 6$ mice. Baseline levels of active and latent MMP-9 were similar between the two mouse strains. This is not unexpected since macrophages are the main source of MMP-9 in aneurysm tissue but are not present in normal aortic tissue [43]. Levels of both latent and active MMP-9 were higher in $129 / \mathrm{SvEv}$ aortas than in $\mathrm{C} 57 \mathrm{Bl} / 6$ aortas in response to $\mathrm{CaCl}^{2}$ - 
treatment. In addition to MMP-2 and -9, other proteases such as MMP-12, MMP- 7, MT1-MMP, neutrophil elastase, and cysteine proteases may contribute to elastin degradation and aneurysm formation [23,24,44-46]. We tested neutrophil elastase expression in the mouse aorta and found no difference between the two mouse strains (Figure 5b). Using EDTA to block MMP activity, it is evident that the majority of the increased elastolytic activity is due to MMPs. These data suggest three possible mechanisms for the increased aneurysm susceptibility in 129/SvEv. First, the larger reservoir of latent MMP-2 could result in more elastin fragmentation with resultant recruitment of inflammatory cells to the aorta. Second, the differences in aneurysm sizes could be related to inherent differences in tissue mechanical properties. Finally, the myelogenous cells of the $129 / \mathrm{SvEv}$ may produce a more vigorous response to injury, greater elastin degradation, and aortic expansion.

It is known that inflammatory infiltrates play a pivotal role in aneurysm formation $[3,5,6,47]$. We investigated whether the myelogenous cell differences between the two strains of mice contribute to aneurysm susceptibility. Two chimeric mice were created, $\mathrm{C} 57^{\mathrm{bkg}} / \mathrm{SvEv}^{\mathrm{bm}}$ mice, hematopoietic tissue ablated $\mathrm{C} 57 \mathrm{Bl} / 6$ mice transplanted with $129 / \mathrm{SvEv}$ mouse myelogenous cells, and $\mathrm{SvEv}^{\mathrm{bkg}} / \mathrm{C} 57^{\mathrm{bm}}$ mice, hematopoietic tissue ablated 129/SvEv mice transplanted with $\mathrm{C} 57 \mathrm{Bl} / 6$ mouse bone marrow cells. Six weeks after $\mathrm{CaCl}^{2}$-aneurysm induction, both chimeric mice produced aneurysms. However, the aneurysm sizes and pathological changes were similar to mice of their genetic background. These results demonstrate that myelogenous cells are not responsible for the background specific differences in aneurysm size between the two mouse strains. Thus, the difference in aneurysm susceptibility is related to tissue properties, MMP expression, or some combination of both.

A genetic predisposition to AAA formation is well-documented $[48,49]$. However, the genetic basis for this predisposition is unknown. Although animal models may not perfectly recapitulate human diseases, they can provide mechanistic insight toward understanding human pathology. The $\mathrm{CaCl}^{2}$-induced murine aneurysm model reproduces many features that have been clinically described in human AAA tissue, including macrophage and T cell recruitment, MMP up-regulation, and elastin fragmentation. Studies have demonstrated that manipulation of MMP-2 and MMP- 9 levels have profound impacts on experimental aneurysm formation $[7,8]$. The current studies extend the previous work in demonstrating that even small differences in baseline or stimulated expression of MMP-2 and MMP-9 affect aneurysm size. Future studies examining factors regulating MMP gene expression will not only provide a greater understanding of the pathophysiology, but also may provide potential targets for therapeutic intervention.

\section{Conclusions}

A better understanding of genetic differences between patients with abdominal aortic aneurysms may help to identify causes of disease susceptibility and aneurysm growth rates. While it is known that abdominal aortic aneurysms run in families, a genetic linkage is currently unknown. This study helps to identify baseline MMP levels and aortic mechanical properties as potential factors that influence aortic aneurysm growth based on comparisons between 129/SvEv and $\mathrm{C} 57 \mathrm{Bl} / 6$ mouse aortas before and after aneurysm induction. This work further extends the knowledge that small changes in MMP expression can dramatically affect aneurysm growth. The differences in arterial stiffness seen between the two mouse strains may help to explain why some patients have a predisposition to develop aortic aneurysms or other vascular pathologies.
Acknowledgments - We thank Lijun Sun for assisting with VVG staining and Anna M. Baxter for assisting with preparation of the figures. This work was supported by the National Institutes of Health NHLBI grant 974015N (to B.T.B).

\section{References}

1 K. Singh, K.H. Bonaa, B.K. Jacobsen, L. Bjork, S. Solberg, Prevalence of and risk factors for abdominal aortic aneurysms in a population-based study : the tromso study, Am. J. Epidemiol. 154 (2001) 236-244.

2 N. Sakalihasan, R. Limet, O.D. Defawe, Abdominal aortic aneurysm, Lancet 365 (2005) 1577-1589.

3 S. Michineau, G. Franck, O. Wagner-Ballon, J. Dai, E. Allaire, M. Gervais, Chemokine (c-x-c motif) receptor 4 blockade by amd3100 inhibits experimental abdominal aortic aneurysm expansion through anti-inflammatory effects, Arterioscler. Thromb. Vasc. Biol. 34 (2014) 1747-1755.

4 Y. Qin, X. Cao, J. Guo, Y. Zhang, L. Pan, H. Zhang, H. Li, C. Tang, J. Du, G.P. Shi, Deficiency of cathepsin s attenuates angiotensin ii-induced abdominal aortic aneurysm formation in apolipoprotein e-deficient mice, Cardiovasc. Res. 96 (2012) 401-410.

5 W. Xiong, Y. Zhao, A. Prall, T.C. Greiner, B.T. Baxter, Key roles of $\mathrm{cd} 4^{+} \mathrm{t}$ cells and ifn-gamma in the development of abdominal aortic aneurysms in a murine model, J. Immunol. 172 (2004) 2607-2612.

6 W. Xiong, J. MacTaggart, R. Knispel, J. Worth, Y. Persidsky, B.T. Baxter, Blocking tnf-alpha attenuates aneurysm formation in a murine model, J. Immunol. 183 (2009) 2741-2746.

7 G.M. Longo, W. Xiong, T.C. Greiner, Y. Zhao, N. Fiotti, B.T. Baxter, Matrix metalloproteinases 2 and 9 work in concert to produce aortic aneurysms, J. Clin. Invest. 110 (2002) 625-632.

8 R. Pyo, J.K. Lee, J.M. Shipley, J.A. Curci, D. Mao, S.J. Ziporin, T.L. Ennis, S.D. Shapiro, R.M. Senior, R.W. Thompson, Targeted gene disruption of matrix metalloproteinase-9 (gelatinase b) suppresses development of experimental abdominal aortic aneurysms, J. Clin. Invest. 105 (2000) 1641-1649.

9 B.A. Kozel, R.H. Knutsen, L. Ye, C.H. Ciliberto, T.J. Broekelmann, R.P. Mecham, Genetic modifiers of cardiovascular phenotype caused by elastin haploinsufficiency act by extrinsic noncomplementation, J. Biol. Chem. 286 (2011) 44926-44936.

10 D. Gauguier, J. Behmoaras, K. Argoud, S.P. Wilder, C. Pradines, M.T. Bihoreau, M. Osborne-Pellegrin, M.P. Jacob, Chromosomal mapping of quantitative trait loci controlling elastin content in rat aorta, Hypertension 45 (2005) 460-466.

11 M. Feng, M.E. Deerhake, R. Keating, J. Thaisz, L. Xu, S.W. Tsaih, R. Smith, T. Ishige, F. Sugiyama, G.A. Churchill, K. DiPetrillo, Genetic analysis of blood pressure in 8 mouse intercross populations, Hypertension 54 (2009) 802-809.

12 Z. Yuan, H. Pei, D.J. Roberts, Z. Zhang, J.S. Rowlan, A.H. Matsumoto, W. Shi, Quantitative trait locus analysis of neointimal formation in an intercross between c57bl/6 and c3h/hej apolipoprotein e-deficient mice, Circ. Cardiovasc. Genet. 2 (2009) 220-228.

13 K. Johansen, T. Koepsell, Familial tendency for abdominal aortic aneurysms, Jama 256 (1986) 1934-1936.

14 H. Kuivaniemi, E.J. Ryer, J.R. Elmore, I. Hinterseher, D.T. Smelser, G. Tromp, Update on abdominal aortic aneurysm research: from clinical to genetic studies, Scientifica 2014 (2014) 564734 .

15 D.L. Rateri, D.A. Howatt, J.J. Moorleghen, R. Charnigo, L.A. Cassis, A. Daugherty, Prolonged infusion of angiotensin ii in apoe(_/_) mice promotes macrophage recruitment with continued expansion of abdominal aortic aneurysm, Am. J. Pathol. 179 (2011) 1542-1548.

16 S. Liu, Z. Xie, A. Daugherty, L.A. Cassis, K.J. Pearson, M.C. Gong, Z. Guo, Mineralocorticoid receptor agonists induce mouse 
aortic aneurysm formation and rupture in the presence of high salt, Arterioscler. Thromb. Vasc. Biol. 33 (2013) 1568-1579.

17 A.P. Owens 3rd, D.L. Rateri, D.A. Howatt, K.J. Moore, P.S. Tobias, L.K. Curtiss, H. Lu, L.A. Cassis, A. Daugherty, Myd88 deficiency attenuates angiotensin iiinduced abdominal aortic aneurysm formation independent of signaling through toll-like receptors 2 and 4, Arterioscler. Thromb. Vasc. Biol. 31 (2011) 2813-2819.

18 A. Daugherty, M.W. Manning, L.A. Cassis, Angiotensin ii promotes atherosclerotic lesions and aneurysms in apolipoprotein e-deficient mice, J. Clin. Invest. 105 (2000) 1605-1612.

19 A. Daugherty, L.A. Cassis, Mouse models of abdominal aortic aneurysms, Arterioscler. Thromb. Vasc. Biol. 24 (2004) 429-434.

20 B.L. Lima, E.J. Santos, G.R. Fernandes, C. Merkel, M.R. Mello, J.P. Gomes, M. Soukoyan, A. Kerkis, S.M. Massironi, J.A. Visintin, L.V. Pereira, A new mouse model for marfan syndrome presents phenotypic variability associated with the genetic background and overall levels of fbn 1 expression, PLoS One 5 (2010) e14136.

21 W. Xiong, T. Meisinger, R. Knispel, J.M. Worth, B.T. Baxter, Mmp-2 regulates erk1/2 phosphorylation and aortic dilatation in marfan syndrome, Circ. Res. 110 (2012) e92-e101.

22 W. Xiong, R.A. Knispel, H.C. Dietz, F. Ramirez, B.T. Baxter, Doxycycline delays aneurysm rupture in a mouse model of marfan syndrome, J. Vasc. Surg. 47 (2008) 166-172 discussion 172.

23 W. Xiong, R. Knispel, J. MacTaggart, T.C. Greiner, S.J. Weiss, B.T. Baxter, Membrane-type 1 matrix metalloproteinase regulates macrophagedependent elastolytic activity and aneurysm formation in vivo, J. Biol. Chem. 284 (2009) 1765-1771.

24 J.L. Eliason, K.K. Hannawa, G. Ailawadi, I. Sinha, J.W. Ford, M.P. Deogracias, K.J. Roelofs, D.T. Woodrum, T.L. Ennis, P.K. Henke, J.C. Stanley, R.W. Thompson, G.R. Upchurch Jr., Neutrophil depletion inhibits experimental abdominal aortic aneurysm formation, Circulation 112 (2005) 232-240.

25 T. Kurihara, R. Shimizu-Hirota, M. Shimoda, T. Adachi, H. Shimizu, S.J. Weiss, H. Itoh, S. Hori, N. Aikawa, Y. Okada, Neutrophil-derived matrix metalloproteinase 9 triggers acute aortic dissection, Circulation 126 (2012) 3070-3080.

26 J. Rivera, L. Tessarollo, Genetic background and the dilemma of translating mouse studies to humans, Immunity 28 (2008) 1-4.

27 P. Demant, Cancer susceptibility in the mouse: genetics, biology and implications for human cancer, Nat. Rev. Genet. 4 (2003) 721-734.

28 C.A. Ruivenkamp, T. Csikos, A.M. Klous, T. van Wezel, P. Demant, Five new mouse susceptibility to colon cancer loci, scc11scc15, Oncogene 22 (2003) 7258-7260.

29 M.J. Maxwell, M. Duan, J.E. Armes, G.P. Anderson, D.M. Tarlinton, M.L. Hibbs, Genetic segregation of inflammatory lung disease and autoimmune disease severity in ship-1_/_ mice, J. Immunol. 186 (2011) 7164-7175.

30 L. Walkin, S.E. Herrick, A. Summers, P.E. Brenchley, C.M. Hoff, R. Korstanje, P.J. Margetts, The role of mouse strain differences in the susceptibility to fibrosis: a systematic review, Fibrog. Tissue Repair 6 (2013) 18.

31 G.M. McKhann 2nd, H.J. Wenzel, C.A. Robbins, A.A. Sosunov, P.A. Schwartzkroin, Mouse strain differences in kainic acid sensitivity, seizure behavior, mortality, and hippocampal pathology, Neuroscience 122 (2003) 551-561.

32 J.M. Dijk, Y. van der Graaf, D.E. Grobbee, J.D. Banga, M.L. Bots, S.S. Group, Increased arterial stiffness is independently related to cerebrovascular disease and aneurysms of the abdominal aorta: the second manifestations of arterial disease (smart) study, Stroke 35 (2004) 1642-1646.

33 M. Pezet, M.P. Jacob, B. Escoubet, D. Gheduzzi, E. Tillet, P. Perret, P. Huber, D. Quaglino, R. Vranckx, D.Y. Li, B. Starcher, W.A. Boyle, R.P. Mecham, G. Faury, Elastin haploinsufficiency induces alternative aging processes in the aorta, Rejuvenation Res. 11 (2008) 97-112.

34 R.B. Hinton, J. Adelman-Brown, S. Witt, V.K. Krishnamurthy, H. Osinska, B. Sakthivel, J.F. James, D.Y. Li, D.A. Narmoneva, R.P. Mecham, D.W. Benson, Elastin haploinsufficiency results in progressive aortic valve malformation and latent valve disease in a mouse model, Circ. Res. 107 (2010) 549-557.

35 C. Lum, E.G. Shesely, D.L. Potter, W.H. Beierwaltes, Cardiovascular and renal phenotype in mice with one or two renin genes, Hypertension 43 (2004) 79-86.

36 A. Hartner, N. Cordasic, B. Klanke, R. Veelken, K.F. Hilgers, Strain differences in the development of hypertension and glomerular lesions induced by deoxycorticosterone acetate salt in mice, Nephrol. Dial. Transpl. 18 (2003) 1999-2004.

37 L.A. Cassis, M. Gupte, S. Thayer, X. Zhang, R. Charnigo, D.A. Howatt, D.L. Rateri, A. Daugherty, Ang ii infusion promotes abdominal aortic aneurysms independent of increased blood pressure in hypercholesterolemic mice, Am. J. Physiol. Heart Circ. Physiol. 296 (2009) H1660-H1665.

38 D.B. Trivedi, C.D. Loftin, J. Clark, P. Myers, L.M. DeGraff, J. Cheng, D.C. Zeldin, R. Langenbach, Beta-arrestin-2 deficiency attenuates abdominal aortic aneurysm formation in mice, Circ. Res. 112 (2013) 1219-1229.

39 X.N. Miao, K.L. Siu, H. Cai, Nifedipine attenuation of abdominal aortic aneurysm in hypertensive and non-hypertensive mice: mechanisms and implications, J. Mol. Cell. Cardiol. 87 (2015) 152-159.

40 D.J. Minion, V.A. Davis, P.A. Nejezchleb, Y. Wang, B.M. McManus, B.T. Baxter, Elastin is increased in abdominal aortic aneurysms, J. Surg. Res. 57 (1994) 443-446.

41 A.M. Houghton, P.A. Quintero, D.L. Perkins, D.K. Kobayashi, D.G. Kelley, L.A. Marconcini, R.P. Mecham, R.M. Senior, S.D. Shapiro, Elastin fragments drive disease progression in a murine model of emphysema, J. Clin. Invest. 116 (2006) 753-759.

42 M. Kunitomo, M. Jay, Elastin fragment-induced monocyte chemotaxis. The role of desmosines, Inflammation 9 (1985) 183-188.

43 V. Davis, R. Persidskaia, L. Baca-Regen, Y. Itoh, H. Nagase, Y. Persidsky, A. Ghorpade, B.T. Baxter, Matrix metalloproteinase- 2 production and its binding to the matrix are increased in abdominal aortic aneurysms, Arterioscler. Thromb. Vasc. Biol. 18 (1998) 1625-1633.

44 J.A. Curci, S. Liao, M.D. Huffman, S.D. Shapiro, R.W. Thompson, Expression and localization of macrophage elastase (matrix metalloproteinase-12) in abdominal aortic aneurysms, J. Clin. Invest. 102 (1998) 1900-1910.

45 G.M. Longo, S.J. Buda, N. Fiotta, W. Xiong, T. Griener, S. Shapiro, B.T. Baxter, Mmp-12 has a role in abdominal aortic aneurysms in mice, Surgery 137 (2005) 457-462.

46 J.F. Woessner Jr., Matrilysin, Methods Enzym. 248 (1995) 485-495.

47 H. Abdul-Hussien, R. Hanemaaijer, R. Kleemann, B.F. Verhaaren, J.H. van Bockel, J.H. Lindeman, The pathophysiology of abdominal aortic aneurysm growth: corresponding and discordant inflammatory and proteolytic processes in abdominal aortic and popliteal artery aneurysms, J. Vasc. Surg. 51 (2010) 1479-1487.

48 C. Armani, M. Curcio, M.C. Barsotti, T. Santoni, R. Di Stefano, M. Dell'omodarme, M.L. Brandi, M. Ferrari, F. Scatena, A. Carpi, A. Balbarini, Polymorphic analysis of the matrix metalloproteinase- 9 gene and susceptibility to sporadic abdominal aortic aneurysm, Biomed. Pharmacother. 61 (2007) 268-271.

49 R.M. Sandford, M.J. Bown, N.J. London, R.D. Sayers, The genetic basis of abdominal aortic aneurysms: a review, Eur. J. Vasc. Endovasc. Surg. 33 (2007) 381-390. 